\title{
Developing Large-Scale Dry Ports-The Case of Arriyadh
}

\author{
Rickard Bergqvist \\ Logistics and Transport Research Group, Department of Business Administration, \\ School of Business, Economics and Law, University of Gothenburg, Göteborg, Sweden \\ Email: rickard.bergqvist@gu.se
}

Received May 1, 2013; accepted June 2, 2013; accepted June 9, 2013

Copyright (C) 2013 Rickard Bergqvist. This is an open access article distributed under the Creative Commons Attribution License, which permits unrestricted use, distribution, and reproduction in any medium, provided the original work is properly cited.

\begin{abstract}
The purpose of this paper is to explore the development process of a large scale dry port and to analyse what measures and actions are needed in order to support the decision making process and ensure an effective and efficient dry port that serves the City and the region's current and future needs. The purpose is explored in the context of Saudi Arabia and the city of Arriyadh. Key issues identified related to the dry port development are long term planning and crosssector collaboration. The interconnection between the dry port and the overall transport system and aspects, such as location of business, city logistics, road and rail infrastructure, local, regional and national regulations, etc., is strong. This puts challenge on the coordination and alignment of the different organizations, their strategies and objectives. In a complex situation, such as developing a dry port with many stakeholders, it is crucial that the roles of all actors are clearly defined. This is essential for utilizing the dry port as a regional tool for planning. In that regard, it is appropriate that the site location decision is clearly connected with an overall city freight vision and strategy.
\end{abstract}

Keywords: Dry Ports; Arriyadh; Development Process; Infrastructure Development; Intermodal Terminal

\section{Introduction}

As urbanization grows and concentration in metropolitan areas increases, the need for efficient and effective transport systems increases as well. The capability of transporting goods to the proximity of cities is thus crucial. Large goods flow in combination with pressure to use sustainable modes of transport results in an increased demand for intermodal transport solutions. As demand for intermodal transport solutions increases, intermodal terminals often find themselves short of the capacity to cope with increased populations and associated goods flows. As a result, many cities now face the relocation and redesign of their transport system in general and the location and design of intermodal transport terminals in particular. At the same time there are constraints on expansion, such as a terminal location that was judged to be at the edge of the city when it was first established that now find itself in a central location due to city expansion. Combined with the demand for land in central areas, there is a pressure to move and relocate large-scale intermodal terminals to less central city locations. This paper examines such a situation: the city of Arriyadh in Saudi Arabia finds itself short of capacity, while at the same time the current intermodal terminal and dry port occupies valuable land in the city center. This paper in- vestigates the development process of identifying suitable locations for a new dry port that better fits the city's overall strategy while simultaneously serving the transport system effectively and efficiently.

Arriyadh is a fast growing metropolitan area whose current population of 5.7 million is expected to exceed 8.3 million by 2030 . It is centrally located in Saudi Arabia and represents a major hub for regional and national transportation. Two major rail lines are currently under development, the East-West land bridge connecting the ports in Jeddah and Dammam, and the North-South-East line connecting the minerals rich North with the industrial areas in the East and the port in Dammam (see Figure 1). These two lines intersect in Arriyadh, turning the City into an important intermodal hub and a central point in the freight and logistics system of the country. In the future, it might also be possible that the northern branch is linked to an international railway connection up north towards central and Western Europe.

Arriyadh faces a strong population growth. The economy depends heavily on the public sector, and this trend is likely to grow even more in the future. The planning authorities already face serious problems and challenges in the fields of energy supply, water and sewerage systems, waste management, urban planning of dwellings, 


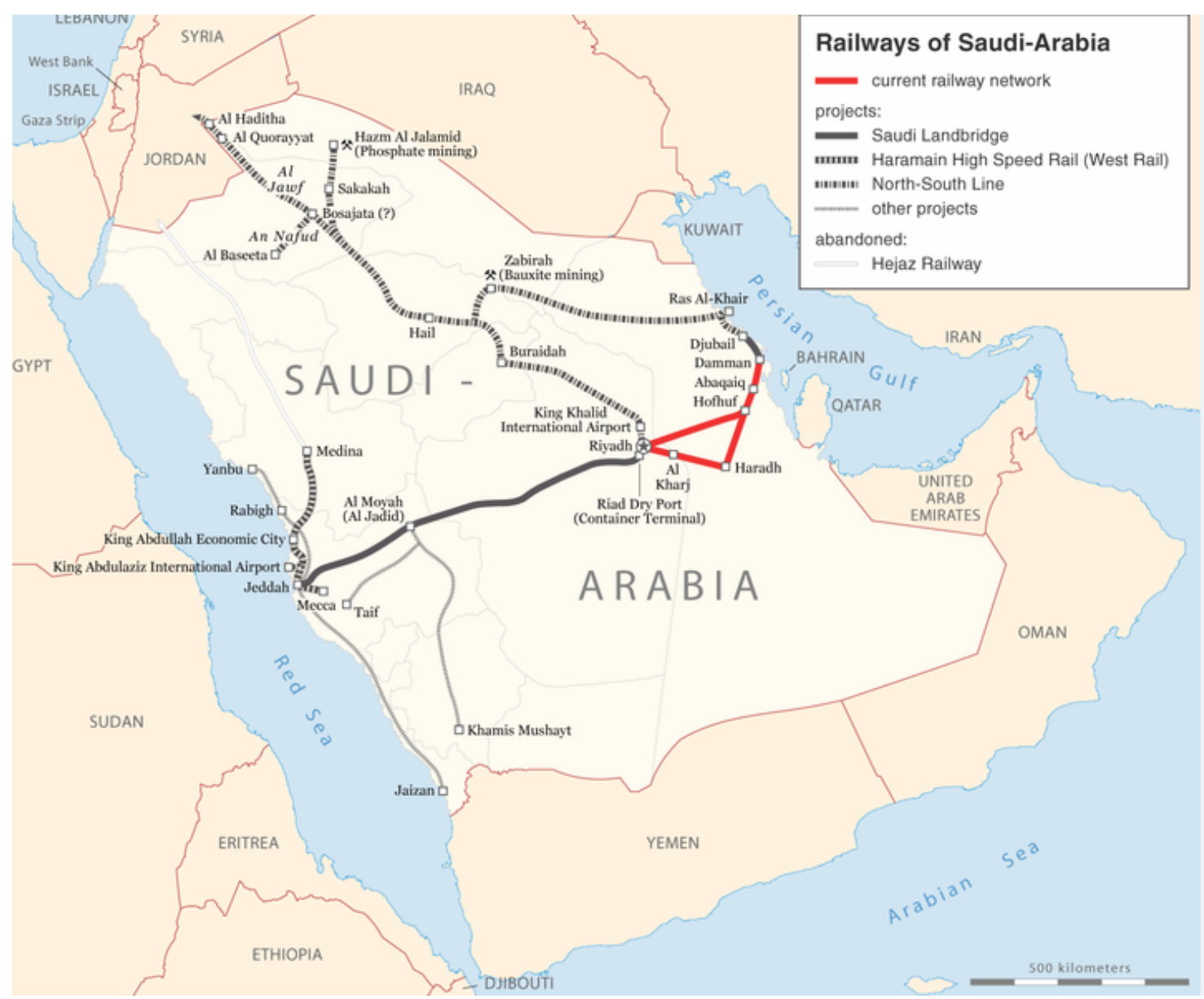

Figure 1. Railway system of Saudi-Arabia [1].

economic development and job creation, and finally transport. The transport system relies on the use of private cars, resulting in increasing commuting to the city centre, traffic congestion, and air pollution.

The authorities meet the challenges of the demographic changes, the transition, and the accompanying problems with an integrated update of current urban planning in the Metropolitan Development Strategy for Arriyah-MEDSTAR. The strategy builds on a common vision of a balanced city plan that could become an international example for the modern urban development of a national capital in the heart of the desert [2].

The MEDSTAR strategy relates also to the development of the transport system. The general strategy is to move the economic activities from the center/south and to create decentralized suburban centers with their own public facilities and economic development zones. The transport strategy is to try to reduce daily commuting by car by building up a system of light rail connections between the suburban centers and city center. The transport strategy is to reduce heavy lorry traffic in congested central areas. This paper addresses part of that strategy by assessing the relocation and developing of a large scale dry port in the city of Arriyadh with the aim of ensuring long term effectiveness and efficiency of goods flows to and from the city of Arriyadh to main connecting seaports.

\section{Purpose}

The purpose of this paper is to explore the development process of a large scale dry port and to recommend which measures and actions are needed in order to support the decision making process and ensure an effective and efficient dry port that serves the city and the region's current and future needs. The purpose is explored in the context of Saudi Arabia and the development process of the relocation of the dry port in the city of Arriyadh.

Any intervention in a complex logistics system must include the current rail terminal (old dry port), the industrial and logistics site to be developed according to the strategic plan, and the new dry port options. It must also include the system of local and regional distribution and warehousing centres in the metropolitan area and its regional hinterland. The purpose has been broken down into three main research questions: 
1) What key location factors can be identified in previous research related to dry port development?

2) How would the dry port function as part of the overall logistics system of the region?

3) What planning and port development and design guidelines can be put in place to ensure that the development of the new dry port is consistent with the City's strategic plan?

\section{The Logistics System and Dry Ports}

The importance of logistics increases as the economy becomes more and more specialised and globalised. Changes in the business environment like globalisation, production patterns [3-6], urbanisation [7], and environmental awareness [8-10] further support this trend. Since production and logistics arrive at the consensus of producing every individual product or module in regions where the comparative advantages are the greatest, there is an increased focus on regions and logistics. The changes in production patterns are supported by the development of cost-efficient transport of goods over long distances $[11,12]$.

The pursuit of higher efficiency and lower costs forces businesses to continuously evaluate locations for production, distribution facilities, competence, etc., in order to establish the optimal locations for their operations. Firms' desire for market expansion and the contemplation of the external forces present in geographical areas steadily increase the importance of regions' attractiveness and competitiveness [11,13-15]. Several researchers $[16,17]$ state that this constitutes a challenge concerning regional business activities. As a consequence, the importance of logistics efficiency and competitiveness of firms and regions increases [18-23]. This development emphasises the connection between the intra-regional transport system, and the larger inter-regional transport system.

The connection between the intra-regional and inter-regional transport systems is the main point of departure since this is often where consolidation and movement between modes of transport are conducted. Consequently, in order to attract and maintain business, a region needs a logistics cost-structure that is competitive. As a result, developing the regional transport system by improving the connection between the intra-regional and inter-regional transport systems is crucial. The performance and the status of the transport system are based upon a set of goal variables. Cost-efficiency, environmental efficiency, and service quality are defined here as the main goal variables and the main performance variables of a transport system. Transport system development characterised by measures of increased consolidation and coordination is related to activities performed at a central node, i.e. a terminal/dry port, and involves the associated actors. Since a central node is also a connection of goods flows, transport resources, and infrastructure, development requires collaboration between actors from different sectors, industries, and businesses. Thus all the actors in the system, separately or jointly, have a responsibility for the status of the system.

The distinction between intermodal/multimodal terminals on the one hand and dry ports on the other hand is essential in the analysis of the goods freight handling options in Arriyadh. The first group of terminals handles goods for a local and regional market, manages different transport modes, and does warehousing and distribution. Typical for a dry port is the integration with sea port systems and its import/export freight flows; it is directly connected to the sea port with rail or inland waterways. Joint IT systems for both ends of the link are fundamental in order to achieve an efficient flow of goods/containers, to see in real time where, when, and how goods/ containers are registered, handled, and transported. A dry port takes over the functions of a sea port, allowing capacity growth in the sea port. The modal shift from road to rail is a basic principle in the dry port concept as the major transport between a sea port and the dry port mainly should be high capacity means of transport, such as rail or inland waterways.

\section{Arriyadh Dry Port}

Arriyadh, $400 \mathrm{~km}$ inland from the nearest port, is currently served by rail from King Abdul-Aziz Portin Dammam (henceforth called Port of Dammam). The terminus of that line, located in the central part of the City, currently serves as its dry port.

The total area of the current dry port is $918,639 \mathrm{~m}^{2}$; this includes (6) warehouses, and the area of each one is $6480 \mathrm{~m}^{2}$ [24]. Currently the dry port handles about 400.000 TEU (twenty foot equivalent units) per year, averaging about 5 trains per day with about 110 containers on each one [24]. This means that it is operating ator close to - its maximum capacity since the dominating container size is 40 feet.

The traffic to and from the dry port consist of shuttle trains to and from the Port of Dammam. As Table 1 illustrates, the Port of Dammam has had strong development in recent years:

Taking into consideration the possibility of traffic to and from the Jeddah Islamic Port (henceforth called Port of Jeddah) and the volumes handled there (see Table 2), there are substantial opportunities for future growth at the Arriyadh dry port.

The growth of the volumes handled at the dry port will continue to follow primarily economic growth but will also get additional support from transport policy reforms and promotion. From GDP growth over the last 10 years (see Table 3), one could expect an annual growth of 
containers of at least $4-6$ percent for the coming years. Container volumes also tend to grow more than the underlying economic growth since the increase in trade usually is more than the corresponding economic growth. At the same time there is a clear trend of containerization, where more and more types of cargo are put into containers.

Translated into dry port volumes, the dry port's activities (handled containers) are likely to double within 5 10 years, boosted by economic growth, more efficient rail and terminal operations, transport policies, and infrastructure investments.

The following utilities are available in the current Dry port [24]:

- A cold warehouse, with an area of $2700 \mathrm{~m}^{2}$, divided into separate sections where different temperatures are maintained according to the requirements.

- A stand-by electricity generator for the dry port and for refrigeration purposes.

- Office premises for the staff of the dry port, the customs department, as well as shipping and customs agents.

- Rail transport for unloading containers from trains to warehouses.

- Shops for repair and maintenance.

- Lifting cranes and gear devices for handling different weights and volumes of goods.

- A fleet of trucks for the local movement of goods from the dry port to the warehouses of merchants.

Table 1. Container volumes at Port of Dammam, 2009-2011 [25].

\begin{tabular}{cccc}
\hline $\begin{array}{c}\text { Containers } \\
\text { (TEU) }\end{array}$ & $\mathbf{2 0 1 1}$ & $\mathbf{2 0 1 0}$ & $\mathbf{2 0 0 9}$ \\
\hline Discharged & 809,871 & 721,018 & 629,873 \\
Loaded & 682,444 & 612,076 & 597,519 \\
Total & $1,492,315$ & $1,333,094$ & $1,227,392$ \\
\hline
\end{tabular}

Table 2. Container volumes at Port of Jeddah, 2009-2011 [25].

\begin{tabular}{cccc}
\hline $\begin{array}{c}\text { Containers } \\
\text { (TEU) }\end{array}$ & $\mathbf{2 0 1 1}$ & $\mathbf{2 0 1 0}$ & $\mathbf{2 0 0 9}$ \\
\hline Discharged & $2,070,791$ & $1,941,623$ & $1,578,515$ \\
Loaded & $1,939,657$ & $1,889,234$ & $1,512,797$ \\
Total & $4,010,448$ & $3,830,857$ & $3,091,312$ \\
\hline
\end{tabular}

Table 3. GDP growth [26].

\begin{tabular}{llllllll}
\hline $\mathbf{2 0 0 1}$ & $\mathbf{2 0 0 2}$ & $\mathbf{2 0 0 3}$ & $\mathbf{2 0 0 4}$ & $\mathbf{2 0 0 5}$ & $\mathbf{2 0 0 6}$ & $\mathbf{2 0 0 7}$ & $\mathbf{2 0 0 8}$ \\
$0.5 \%$ & $0.1 \%$ & $7.7 \%$ & $5.3 \%$ & $5.6 \%$ & $3.2 \%$ & $2.0 \%$ & $4.2 \%$ \\
$\mathbf{2 0 0 9}$ & $\mathbf{2 0 1 0}$ & $\mathbf{2 0 1 1}$ & $\mathbf{2 0 1 2}$ & & & & \\
$0.1 \%$ & $4.6 \%$ & $6.8 \%$ & $6.0 \%$ & & & & \\
\hline
\end{tabular}

- An integrated security system.

- 84 residential units for staff, including a mosque, a restaurant, and a clinic.

Services at the dry port:

- Receipt of consignments, which include containers, vehicles, equipment, and general merchandise consigned directly from the Port of Dammam, and customs clearance thereof at the Arriyadh dry port to be delivered to their respective owners.

- Preparation of all documents pertaining to receipt, storage, and inspection by the customs of all goods entering the dry port area, as well as documentation concerning receipt of such goods by the importers.

- Return of the empty containers to the shipping agents in Dammam after the goods consigned under the containers were inspected by the customs officials and such goods were finally received by their owners.

- Receipt and handling of containers destined for export from Arriyadh until they are finally placed on the vessels at the Port of Dammam.

- Maintenance and repair of all kinds of equipment, cranes, and lifting gear devices required for the efficient operation of the dry port.

- Receipt of refrigerated containers for perishables and the maintenance of temperatures required for the goods, whether inside the container or during storage in the cold storage warehouses at the dry port.

- Receipt and handling of non-container cargos such as steel, timber, pipes, etc. from the Port of Dammam.

- Notification to the shipping agents about the arrival of imported goods, so that they could inform their principals to receive their goods within the allowed period of time.

- Handling, loading, and discharge of automobiles imported through the Port of Dammam.

Today, a lot of the break-bulk activities are carried out within the dry port itself; in the future, it is likely that a larger part of these activities will be carried out by actors and companies outside the dry port that specializes in specific type of freight, technologies, or customers.

In sum, the facility is dated, overloaded, and cannot sustain the current demands of Arriyadh's booming economy, much less the growth anticipated in the coming years.

\section{The Proposed Sites for the New Dry Port}

As part of its metropolitan strategic planning, the Arriyadh Development Authority prepared and the Government approved a Metropolitan Strategic Plan for Arriyadh (MEDSTAR). The plan provides a vision and a structure for Arriyadh to 2030. It envisions the development of growth spines, sub-centers, and suburbs all aimed at guiding the growth of the city in a manner that meets its socioeconomic and environmental goals. An 
element of this structure creates an economic development zone in the Eastern suburb of the city. This zone is designed to be adjacent to the rail line and would include the site of a new dry port to serve the city's current and future needs. Associated with that location, the plan also envisages the development of related sectors of industry and logistics as well as supporting economic activities.

Since the adoption of the MEDSTAR plan, the railroad network plan has changed, and the option of connecting the east logistic site has disappeared in favour for a new northern railway branch closer to the central city. These results in a configuration whereby the two main rail lines intersect at a location in the southern sector of the city, creating an opportunity for a dry port location, see Figure 2. This represents a major departure from the structure plan of the city and requires a review of the implications of this new siting on the integrity of the plan and of the measures necessary, if any, to ensure that the dry port would be integrated with the rest of the urban and regional system it serves.

\section{Dry Port Assessment}

From previous studies and international experience, the following key factors in location and development of dry ports have been identified: connectivity, location, system thinking and area for expansion, market, long-term planning and cross-sector/organizational collaboration, clear roles of public and private sector, and dry port as a regional tool for traffic planning.

\subsection{Connectivity}

The city of Arriyadh overall has well-functioning and efficient services to Dammam. Several upgrading projects are ongoing, related to infrastructure development of the new lines east-west and north-south. The south location is located in direct connection to the two lines. Upgrade projects, such as the increased axle weight on the link Dammam-Arriyadh, will significantly improve throughput. Both locations have good road connections (regional roads) and are close to future ring roads. The

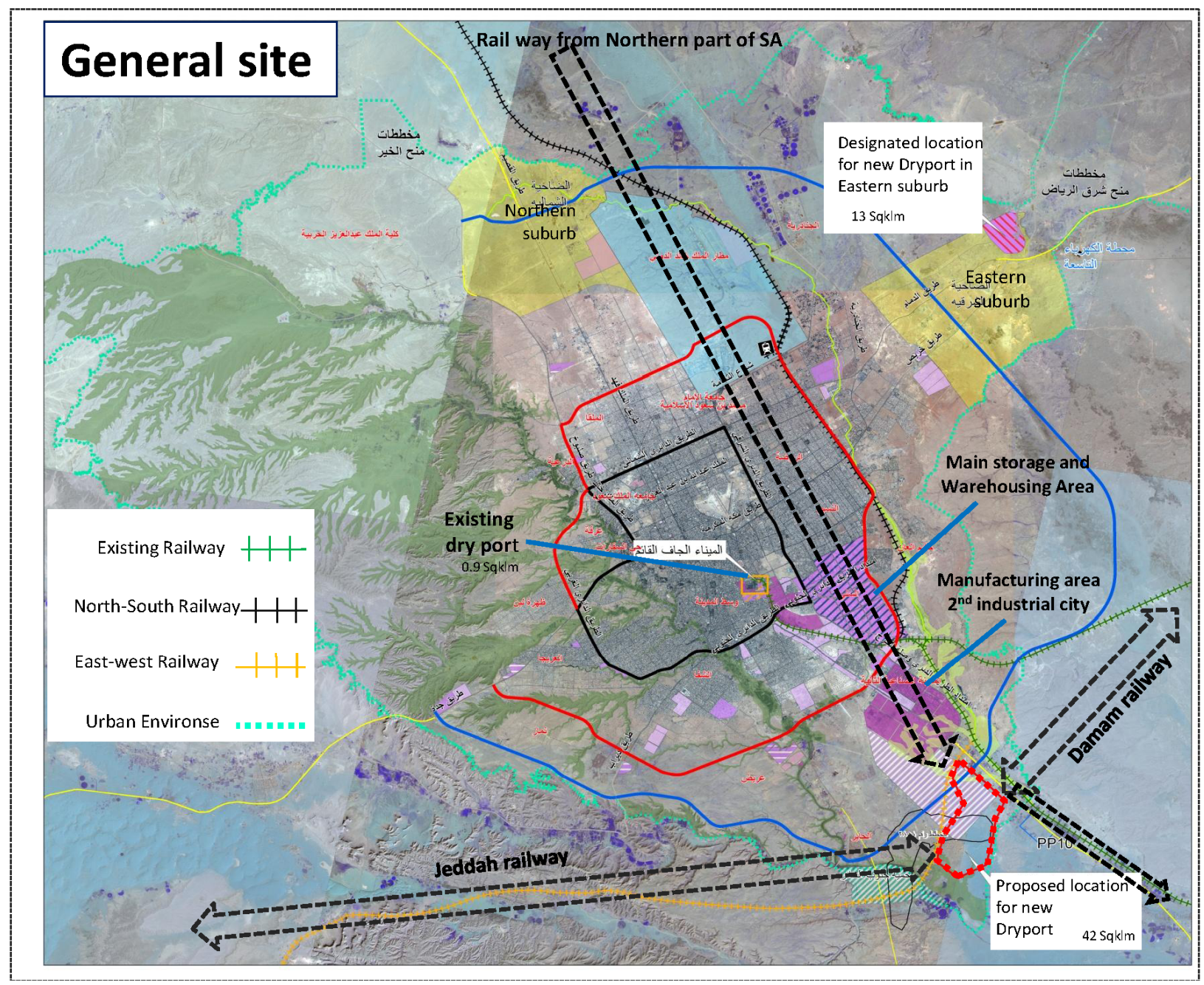

Figure 2. Map of Arriyadh and the proposed dry port locations [27]. 
future third ring road is slightly closer to the southern location. The northeastern location seems to be located closer to planned areas for housing and related functions compared to that of the southern location. The southern location has less conflict between freight and passenger transport.

A marshaling yard is probably needed in the future, creating high demand for available land. There are great synergies with colocation between the marshaling yards and the dry port; this further emphasizes the advantage of the southern location, given land availability and connectivity to the two main rail lines. This emphasizes the importance of high integration and planning between railway operator/operations and dry port operator/operations. Joint development and coordination with the Port of Dammam in order to improve infrastructural interchange between the port and dry port is important.

\subsection{Location, System Thinking and Area for Expansion}

It is important to have areas for expansion in order to ensure that the site is sustainable for future growth. A site that can contain future growth will avoid a future necessary reallocation. The southern location fulfills this criterion; at the same time, there is little competition with areas for residence. Area for expansion also provides flexibility in enabling further expansion of rail infrastructure and rail connected plots and businesses.

The southern alternative is closer to existing and planned areas for warehousing and manufacturing. This gives capacity to lower cost and improved LCL delivery and on time efficiencies. At the same time, the southern location is not adjacent to major suburban areas, meaning less amenity impact. A location outside the city boundaries is regarded as unfavorable since it would be too far from the major industrial area in the south.

Both sites have generous areas for expansion; however, the southern location seems to have greater possibilities since it is bigger, but there are also large areas for development assigned to warehouse and industry purposes adjacent to the site. The southern site has larger available space, enabling connecting activities such as empty container deports.

\subsection{Long Term Planning and Cross-Sector/Organizational Collaboration}

It is necessary and desirable for all involved actors and organizations to remain committed to and informed of the project. It is important that the actors and organizations keep collaborating and maintaining communication. There are three main components of collaboration for the purpose of planning, regulation and institutional structure. Fragmentation of these elements may dissolve efficien- cies. Clarity around project objectives would support the required collaboration. It would be beneficial if one dedicated body took an overall coordinating function.

\subsection{Clear Roles of Public and Private Sector}

In order to ensure long term planning effectiveness and an overall efficient transportation system, it is important to clarify the role and responsibility of different private and public actors/sectors in the development process.

\subsection{Dry Port as a Regional Tool for Traffic Planning}

The dry port can be used as a powerful tool for regional planning since the dry port will act as a magnet for business allocations and establishments. From the perspective of available and dedicated land for industry use, it seems as the southern location has an advantage compared to the northeast location. This is especially important when looking at the historical and forecasted congestion situation for the city of Arriyadh, as illustrated in Figure 3.

Table 4 illustrates the assessment of the possible site location based on key location determinants and factors.

From the assessment it is evident that Option 2 is favorable. This site is superior in all major criteria, espe-

Table 4. Assessment of the two location alternatives (Option 1: Designated area in the east. Option 2: South location).

\begin{tabular}{ccc}
\hline Key factors & Option 1 & Option 2 \\
\hline Connsectivity & - & ++ \\
Rail & - & + \\
Road (regional/ring roads) & + & ++ \\
Closeness to housing/passenger & - & + \\
Airport & N/A & N/A \\
Market (existing and new business) & + & ++ \\
Location, system thinking and area \\
for expansion
\end{tabular}

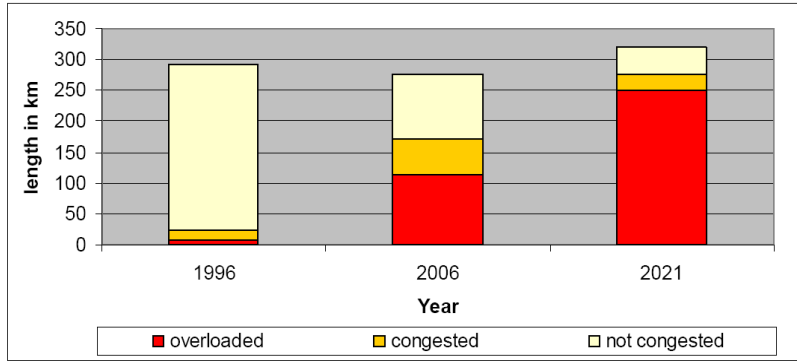

Figure 3. Congestion forecast [2]. 
cially closeness to the market (existing and new areas for industry) and connectivity to road and rail since Option 2 is located close to existing industry areas. The majority of freight transported to the dry port in Arriyadh has its destination in the industrial area in the south, further emphasizing the superiority of Option 2 and its closeness to the market. The location becomes even more evident now when the Port of Dammam is determined to strengthen the rail freight to/from the port with investments in rail facilities in the port. While a decision in the south is logical in operational terms, it is likely to be the lowest cost in the sense of rail operations and is going to provide good road linkages. Therefore it will not likely be any worse than alternatives in road distribution costs, hence further consideration of distribution costs are not necessary before a decision is made.

\section{Logistics System Interaction}

The new dry port location has some main interactions with the overall logistics system. Firstly, the dry port function is central and will act as a center of gravity for business locations and development. This creates great demand for available land for development, which is present for Option 2. The magnitude of the flows and the related road traffic also creates high demand for good connections to the supra-infrastructure (e.g. ring roads). However, closeness to the airport is judged to be of subordinate importance.

Regarding the old dry port location, it could have important alternative uses. It may have a great value for future development of public transportation and public space in the city center. It is a great area for expanding the central station and related public transport such as bus routes, etc. During a transition period from the point of moving the Dry port to the new location, the area of the old dry port could be used as a node/center for construction work being carried out in the city center, e.g. public transport infrastructure projects. The site could be used for bringing in construction material by rail to the city center. Other possible uses could be as a crossdocking function. Primary goods could then be groceries, perishables, reefers, etc. Other possible uses could be the transport and storage of imported cars.

The designated site in the eastern parts of the city as decided upon in the MEDSTAR planning exhibits the following characteristics. It is situated at the road connection from the Port of Dammam, which stands for $60 \%$ of the currently incoming goods flows from the port [25]. This road transport now continues through high-traffic central roads to the existing dry port. Congestion problems have led to restrictions for heavy lorry transport at certain times, and the expectation is that a dry port site development would reduce heavy traffic in the city centre. More decisive in the decision to plan a dry port to the east seems to be a wish to decentralize the economic areas and to create new job opportunities in the sub-urban residential areas, partly with the expected effect of decreasing commuting to central parts for the people working at the site. However, experiences show us that logistics facilities such as dry ports do not create a lot of direct employment in relation to the land used. This means that the impact on employment would not be that influential when choosing another site for the dry port. The number of direct jobs in the dry port is estimated at a maximum 100 - 200 people, many of them living in houses in the dry port today.

The proposed location in the eastern parts could have a number of alternatives uses, e.g. light industry, service (car service and maintenance, petrol stations, etc.), wholesaling (shops, wholesalers, supermarkets, etc.), and warehousing. One of the advantages of this location is the closeness to the airport, and for that purpose the site is still very attractive for logistics activities such as warehouses related to air transportation. There is no or very little competition between the proposed eastern location with that in the south since there is very little interaction between the dry port and the airport. There is a large traffic flow of heavy trucks to and from Damman that would exist even if the new dry port is constructed. Thus the proposed area in the east would be an attractive and suitable area for this traffic and activities since it is close to the highway and not to close to the city, which means that the presence of heavy trucks in the center of the city would be decreased. There are possibilities to create a logistic platform in the east that takes care of the incoming road bound goods flows from the Portof Dammam. It would allow a restriction policy for the city centre as heavy lorries can reach the outskirts of the city. It would require smart city logistic solutions with light-weight, smaller lorries, that can provide the inner city with goods. If such a city logistics is chosen it could be considered for a type of city transport that uses alternative fuels with more environmentally friendly characteristics. Better road access should be developed to connect the logistic platform in the east with the planned ring road. It is important that the planning guidelines/ provisions for this site/area ensure that no heavy industry is developed in this area. Overall, strong road volumes to and from Dammam and possible connections to the airport provide opportunities for logistics activities and services. This area would facilitate transport planning objectives by being a major platform/split hub for truck movements related to the city. Consideration could be given to forbid heavy trucks to go inside the third ring road. They could then use the third ring road to connect the distribution center with the dry port in the south. Ring road connection from the center could also be considered as a specific dedicated freight road using specific tech- 
nology and a user pays model. The option of a logistics platform also opens up the possibility for a smart city logistics system.

From international experience, most major cities have with development of their ring roads and freeway systems seen development of supporting logistics centers for receiving deliveries by road. The logistics centers have shifted from the inner city, given the increasing size of vehicles and the value of land, which then allows proper inventory management in a mix of vehicle size with a dramatic increase of light commercial vehicles. This would occur here in the east.

\section{Conclusions}

This paper offers an overview of relevant factors related to the development of a large-scale dry port in a metropolitan context. The focus of this paper is to explore the issue of the implications of the siting of the dry port and to analyze what measures, actions, or policies are needed in order to ensure that the dry port will function effectively and efficiently and serve the city and the region's current and future needs. The conclusions are structured in accordance with the defined research questions.

\subsection{Long term Planning and Cross-Sector/Organizational Collaboration}

The interconnection between the dry port and the overall transport system, such as location of business, city logistics, road and rail infrastructure, local, regional and national regulations, etc., is intimate. This means that the development process creates challenges for the coordination and alignment of the different organizations and their strategies and objectives. It is important in a complex situation, such as when developing a dry port with many stakeholders involved, that the roles of all actors are clearly defined. This is essential for utilizing the full opportunity of using the dry port as a regional tool for planning. It would be beneficial if one dedicated body took an overall coordinating function. However, once a site is chosen, project objectives need to be agreed upon until the supporting institutional structures are put in place.

\subsection{Dry Port Function as Part of the Overall Logistics System}

The former dry port location may have great value for future development and long term plans for public transportation in the city center since the rail infrastructure is already in place. There might also be an interesting possibility during a transition period where the site would be possible to use for other purposes. It could work as a center for LCL cargo, reefers, or similar cargo with special demands. It could also function as a center for con- struction work activities related to public transport such as storage of material and bringing in material by rail. Either way, the area is of such value that it should be used even if the transition period is just a few years.

\subsection{Planning, Development, and Design Guidelines}

From a city perspective, a number of available measures exist related to the operating and design framework of the dry port. An example of possible and commonly used measure that is used to support the overall project objectives of dry ports is to give priority for establishments heavily dependent on transport in general but especially rail. Another measure and requirement related to the housing of workers might be to require the dry port to provide housing for a certain share of the employees. It should also reflect over the public transport facilities for its workers in order to get to/from the dry port conveniently. Another issue that must be considered in order to limit the effects of the dry port operations on surrounding areas is to ensure that the site design enables all trucks to be parked inside the premises of the dry port and the operating hours. In order to facilitate transport efficiency and limit pre- and post-haulage to and from the dry port, surrounding areas can be designated for businesses that focus on logistics and warehousing. Such establishments may even have a certain modal share targets set by the city. The aim is a good mixture of guidelines and policy requirements that facilitate the development process.

When it comes to the design of the dry port there are several important considerations. The success of a new dry port is highly dependent on its effectiveness, efficiency, and service quality. This is a principal concern for the design of the dry port. Figure 4 illustrates the general principles of the design and layout. For future needs, the design of the Arriyadh Dry port should also open up a possible functional extension of a marshaling yard.

The case of the Arriyadh dry port illustrates a situation many metropolitan areas are facing today with an outdated and congested dry port situation. Relocating and redesigning the dry port creates great opportunities for improving the effectiveness and efficiency of the transportation system. At the same time it creates the challenge of how to combine it with the overall objectives and strategies of the city. This, in combination with the vast number of stakeholders involved, makes the development process extremely challenging and difficult to manage.

To sum up, the interconnection between the dry port and the overall transportation system and aspects such as location of business, city logistics, road and rail infrastructure, local, regional and national regulations, etc. is strong. This puts challenge on the coordination and 


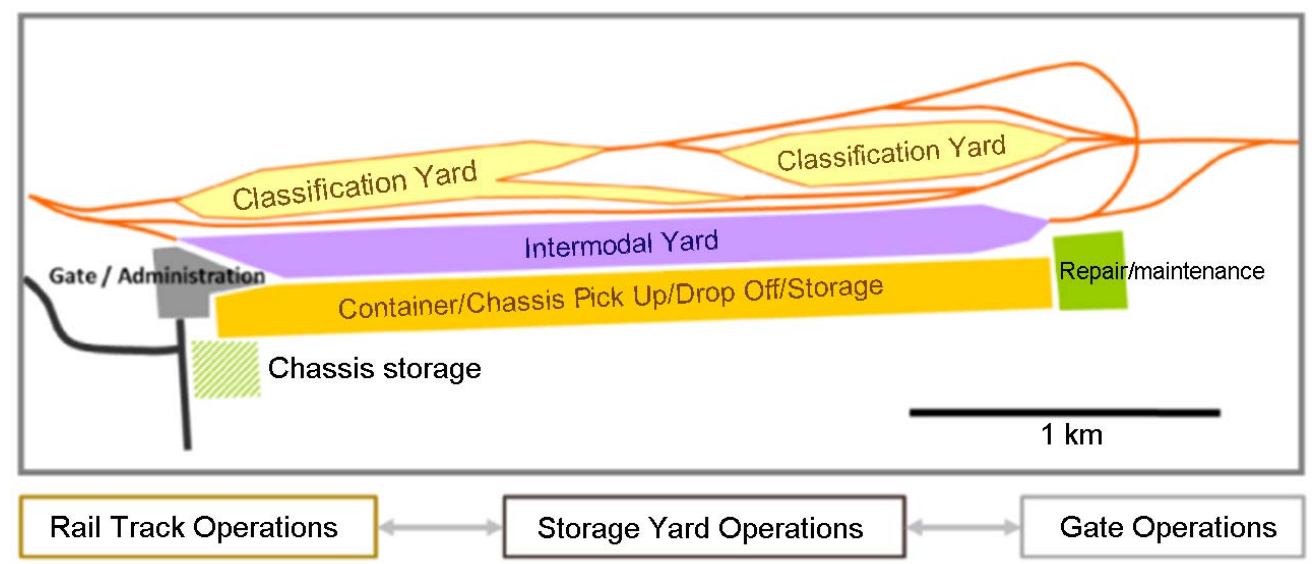

Note: Modeled after the Bedford Yard in Chicago, owned by CSX.

Figure 4. Functional layout of a large-scale intermodal terminal [28].

alignment of the different organizations, their strategies and objectives. In a complex situation, such as developing a dry port with many stakeholders involved, it is crucial that the roles of all actors are clearly defined. This is essential for utilizing the dry port as a regional tool for planning.

\section{REFERENCES}

[1] Wikipedia, "Saudi Railways Organization," 2013. http://en.wikipedia.org/wiki/Saudi_Railways_Organizatio $\mathrm{n}$

[2] Arriyadh Development Authority, "Medstar Update 2009," Metropolitan Development Strategy for Arriyadh, Arriyadh Development Authority, Riyadh, 2009.

[3] A. Das and R. Handfield, "Just-in-Time and Logistics in Global Sourcing: An Empirical Study," International Journal of Physical Distribution \& Logistics Management, Vol. 27, No. 3/4, 1997, pp. 244-259. doi:10.1108/09600039710170601

[4] D. S. Búrca, "Core-Peripheral Relationships as the Nexus in World Trade Trends," In: B. Fynes and S. Ennis, Eds., Competing from the Periphery, The Dryden Press, London, 1997, pp. 17-45.

[5] R. O'Donnel, "The Competitive Advantage in Peripheral Regions: Conceptual Issues and Research Approaches," In: B. Fynes and S. Ennis, Eds., Competing from the Periphery, The Dryden Press, London, 1997, pp. 47-82.

[6] EuroCase, "Freight Logistics and Transport Systems in Europe," Project Report, The European Council of Applied Sciences, Technologies and Engineering, Paris, 2001, p. 208.

[7] A. Scott and M. Storper, "Regions, Globalization, Development," Regional Studies, Vol. 37, No. 6/7, 2003, pp. 579-593.

[8] C. Lammgård, "Environmental Perspectives on Marketing of Freight Transports-The Intermodal Road-Rail Case, Logistics and Transport Research Group, School of
Business, Economics and Law," Ph.D. Thesis, Göteborg University, Göteborg, 2007, p. 242.

[9] IPCC, "Climate Change 2007: The Physical Science Basis, Summary for Policymakers," Intergovernmental Panel on Climate Change, Geneva, 2007.

[10] European Commission, "White Paper-European Transport Policy 2010: Time to Decide," Office of Official Publications of the European Communities, Luxembourg, 2001.

[11] L. Nordström, "Volume 15: European Developing Regions-Reality or Chimera?" In: J. Alden and P. Boland, Eds., Regional Development Strategies-A European Perspective, Jessica Kingsley Publishers, London, 1996, p. 322.

[12] J. J. Coyle, E. J. Bardi, et al., “Transportation,” Thomson Learning, Cincinnati, 2000.

[13] A. P. Trunick, "Location, Location, Logistics - The Three Most Important Factors in Site Selection," Transport \& Distribution, Vol. 43, No. 3, 2002, pp. 24-34.

[14] C. Kamsvåg, "Transporter för Tillväxt—Vägar Framför IT," Företagarnas Riksorganisation, Stockholm, 2000.

[15] R. Bergqvist, "Hinterland Logistics and Global Supply Chains," In: D.-W. Song and P. Panayides, Maritime Logistics-Logistics Management of Shipping and Ports, Kogan Page, London, 2011.

[16] F. Barry, J. Bradley, et al., "Economic Structure and Change in the EU Periphery," In: B. Fynes and S. Ennis, Eds., Competing from the Periphery, The Dryden Press, London, 1997, pp. 117-146.

[17] P. Kotler, C. Asplund, et al., "Marketing Places Europe," Pearson Education Limited, London, 1999.

[18] A. McKinnon, "Logistics, Peripherality and Manufacturing Competitiveness," In: B. Fynes and S. Ennis, Eds., Competing from the Periphery: Core Issues in International Business, The Dryden Press, London, 1997, pp. 335-369.

[19] R. Bergqvist, "Hamnpendlarnas Betydelse för det Skandinaviska Logistiksystemet," Handelshögskolan vid Göte- 
borgs Universitet, Göteborg, 2009.

[20] R. Bergqvist, J. Woxenius, et al., "Establishing Intermodal Terminals," World Review of Intermodal Transportation Research, Vol. 3, No. 3, 2010, pp. 285-302. doi:10.1504/WRITR.2010.034667

[21] R. Bergqvist, G. Wilmsmeier and K. Cullinane, "Introduction-A Global Perspective on Dryports," In: R. Bergqvist, G. Wilmsmeier and K. Cullinane, Eds., DryportsA Global Perspective, Challenges and Developments in Serving Hinterlands, Ashgate Publishing Limited, Farnham, 2013.

[22] R. Bergqvist, "Hinterland Transport in Sweden-The Context of Intermodal Terminals and Dryports," In: R. Bergqvist, G. Wilmsmeier and K. Cullinane, Eds., Dryports-A Global Perspective, Challenges and Developments in Serving Hinterlands, Ashgate Publishing Limited, Farnham, 2013,
[23] G. Wilmsmeier, R. Bergqvist and K. Cullinane, "Ports and Hinterland-Evaluating and Managing Location Splitting," Research in Transport Economics, Vol. 33, No. 1, 2011, pp. 1-5. doi:10.1016/j.retrec.2011.08.001

[24] Saudi Railways Organization, "The Riyadh Dry Port," 2013. http://www.saudirailways.org

[25] Saudi Arabian Ports Authority. http://www.ports.gov.sa

[26] International Monetary Fund (IMF)—World Economic Outlook April 2012.

http://www.imf.org/external/pubs/ft/weo/2012/01/weodat a/index.aspx

[27] Arriyadh Development Authority. http://www.ada.gov.sa

[28] J. P. Rodrigues, "Configuration of a Rail Intermodal Container Terminal," 2013. http://people.hofstra.edu/jean-paul_rodrigue/ 